\title{
Illocutionary Act in Anger Management Movie
}

\author{
Feky Ega Situmorang1, Nurma Dhona Handayani² \\ fekyega96@gmail.com ${ }^{1}$, nurmadhona@gmail.com ${ }^{2}$ \\ 1,2.Universitas Putera Batam (UPB), Batam, Indonesia
}

Received: 26 June 2020 Accepted: 30 June 2020

DOI: $10.24256 /$ ideas.v8i1.1424

\begin{abstract}
The purpose of the research was to find out the types of illocutionary act on Anger Management movie written by David Dorfmann. The data of this reserach were taken through observational method. The technic of the research used non-participatory. It was a descriptive qualitative research. The data analyzed used the theory of Searle and Austin. The result of this research there were 20 data utterances of illocutionary acts. The data was 8 showed directives, 1 showed assertives, 2showed commisive, 5showed declarative, 4and showed expressive. The data were consisted of five types: directives, assertives, commisives, declarative, and expressives. From all the data, the most used type of illocutionary acts was data for directive. The reason was because some people wanted to describe their feeling through their expression and people also liked to asked people not to do or do something by using directive illocutionary act.
\end{abstract}

Keywords: Pragmatics, Speech act, Illocutionary acts, directive 


\section{Introduction}

There are many uses of media that have function as a tool for communication; movie is one of the examples. Movie is a communication media in which there is a series of stories built by the characters through spoken dialogues. Movie is one of the literary works that are based on imaginative story ideas and facts. In the conversation of the characters in the movie, there is dialogue in the form of speech.

Hughes (1984) said, "The speech act is the act of conveying something of related intent". It is the act of the speaker did through words that contain more specific words, such as apologies, complaints, compliments, invitations, promises, or request. In speech acts, when people sent information, they have intended that the message was sent, the listener will do something. Speech is a language used by people to communicate is part of pragmatics..

Jacobs (1989) consisted of three parts; illocutionary, perlocutionary, and locutionary act. The first is locutionary act (an act of saying something) that merely conveys the actual sense of utterances. Or, it can be assumed that locutionary act is the textual meaning of a speaker's utterance. Secondly, there is a perlocutionary act (the act of affecting saying) and the third is illocutionary act (an act in doing something) that sets a role for the intent.

This research focused to the analysis of illocutionary act. Searle (1968) classified types of illocutionary act into five; directive, assertive, commisive, expressive and declarative. The 5 types were used for saying something from the speaker's intention within utterances. Illocutionary acts itself can be found in communication activities in daily life. Such conversations were found in several media, such as films. Film is one of the influential media than other media because as audio and visual, they work together to make viewers interested in watching. Movie script is the source that was taken by the researcher. To study illocutionary act, the researcher took movie, entitled Anger management, and a film with a comedy genre that contains psychological messages in it.

This film told about an executive assistant named Dave. Dave is a very shy person and cannot pour out his anger at people who have made him hate or who have underestimated him. Dave felt bored and angry with himself because he could not shed his anger where it should be. Especially when Dave was in a love affair with Linda. Therefore, Linda wants Dave to turn into a normal man who can control his emotions so that their relationship gets better. Linda made a plan with a doctor named Buddy. And this is a new part of Dave's life. The plan began with problems on the plane until brought Dave to court and was put into an emotional control group under the care of Doctor Buddy.

There is still a lack of references regarding the analysis of illocutionary speech acts on Anger management movie, making researchers interested in studying illocutionary speech acts in Anger management movie. From this explanation the researchers chose to analyze this movie.

For supporting the research, the researcher showed two journal which 
related the same topic with this research. The researcher choosed two journals which discused on illocutionary act. The first journal Sembiring (2019) discussed the types and function of illocutionary act in the Alladin movie. Aziz, Mahdi, \& Amalia, (2017) discussed directive speech act and function of illocutionary act in Mario Teguh talkshow. The reason of the researcher choosed the topic because illocutionary act had intended meaning. The intended meaning can be interpretedin every speaker's utterance and most speakers did not understand that they had did illocutionary acts in their speech. The purpose of the research were discussed the types of illocutionary act in Anger Management movie. The limited the problem only the types of illocutionary act choosed by the researcher. The research which choosed by the researcher focused to utterance on dialogue of illocutionary on Anger Management movie. The object of the research was Anger Management movie because the movie contained a thing which related to topic that the researcher choosed.

Pragmatics is one of branch linguistics that studies the language used to communicate in certain situations. Pragmatics also related to context of the utterance in communication. Speech in pragmatic studies can be understood as a form of speech acts themselves and as a result of a speech act.

According to Austin speech act had theory by categorizing speech into two types, namely constative and performative. The first category, namely the constative utterance, is "to say something" that has property becomes true or false Austin (1962). So the constative includes all descriptive remarks, statements of fact, definitions and so on; that is speech that reports, informs, and states Searle (1969). For example, the statement "The corruptors are that person" spoken by a witness in court has the consequences of evaluating right or wrong on the contents of the speech.

The second category, namely performative is speech, Speech is not speech aimed at explaining, stating, or all description speeches, which have the consequence of evaluating whether or not the speech or proposition is spoken. Performative speech forms or creates action. For example the utterance "the road was slippery" what is said seriously will have the effect of attentions on the speech partner, not because the contents of the speech are true or false (whether there really is a rain or roadwork), but because the speech is a warning or an act of warning.

After dividing the speech into two, namely constative and performative, Austin also proposes the division of speech acts into three, namely acts of locution, illocution, and perlocutionary. Illocutionary act, namely the act of doing something based on what was said. Illocution is what is achieved by communicating the intention to achieve something. Speech can contain certain "power".

Through speech people can create something new, can make people do something, change the situation, and others. "I am father ..." when it was said by the man to have created something new, that from then on the couple who had 
daughter became parents and could live together to keep daughter. The words "I am father ..." cannot be said to be true or false if spoken in a suitable condition that is said by someone who has the authority to keep and care the daughter.

Thus the speech is not a description, but states the state of events that would occur if the statement was made sincerely and intended in appropriate circumstances Therefore illocutionary is not descriptive and is not subject to conditions of truth; it is a performance of an act in saying something.

According to Searle in G. Leech (1989) the classification of illocutionary acts in to five main types:

\section{1) Assertives}

Assertives are acts which commit the speaker to something being the case to the truth of the expressed proposition. The examples of this acts are such as stating, suggesting, boasting, complaining, claiming, and reporting. In uttering an assertive, a speaker conveys his/her belief that some proposition is true. For example "Indonesia must have actions to resolve protracted cases such as illegal fishing". Based on the example the utterance that produced by the speaker contained complaining to government.

\section{2) Directives}

Directive is used by the speaker to get the addressee to do something. It intends to produce some effects through action on the listener. By uttering a directive, the speaker attempts to get the listener to do something. By ordering, commanding, requesting, advising, asking, begging, biding, demanding, forbidding, and recommending, the speaker is trying to get the listener to carry out action. For example: "would you come to my party tonight?". Based on the example that used by the speakers in asking someone else to do something for them. It means that if through speaker's utterance the speaker aims to make other people or hearer doing something for him/her.

3) Commisives

Commissives are acts which commit the speaker to some future course of action. By uttering commisives, the speaker is committing himself or herself to some future course of action. Some examples are promising, vowing, offering, volunteering, pledging and betting. For the example: at the phone "I will arrive at 7o'clock to your office". Based on the example the speakers act that he/she commit to arrive. It means that promising something to the hearer in the future.

4) Expressive

Speakers of a language often express feelings to the listener when they speak. By doing so, the speakers have performed the expressive acts. Expressive are speech acts which express a psychological state. They have the function of expressing, or making known, the speaker's psychological attitude towards a state of affairs which the illocution presupposes. For example: "thank you". Based on the utterance, the speakers express thanking to other about he/she had help him/her.

5) Declaratives 
As Searle in Yule (2010) stated that declarative is kinds of speech act that change the world via their utterance. When the speaker utters a declaration, his or her words bring about a new state of affair. It can be changing of the status of a person or, the ownership of something. The verbs which belong to declaration are: appointing, baptizing, declare, naming, and resigning. For example: at the office the supervisor said that time out!. Based on the example the supervisor declare for the test finished, so the employee must collect the test.

\section{Method}

The researcher used qualitative descriptive to examine the types of illocutionary actions contained in the Anger management movie, the qualitative approach is typically used in research to explain or analyze the data.

The method used for this research is documentation. Data from the movie was collected, reviewed, and then analyzed to form a kind of conclusion. Thus, the research data analysis technique can be explained as follows:

(1)Watch a movie several times

(2) After the researcher watched the movie, the researcher reads the script.

(3) Watched a movie while reading the script and make some brainstorming to build an analysis based on data.

(4) The researcher determined the type of illocutionary act.

(5) Gather utterances from dialogue in movie.

(6) Identify data based on the type of illocutionary act.

In analyzing the data, the researcher applied theory from Sudaryanto (1993). There are some procedures, the steps that are taken in the process analyzing the data in this study are as followed.

(1) Analyzing the types of illocutionary actbased on the theory.

(2)The data were described to answer those categories based on research question.

The researcher used informal method which informal method refers to the process of presenting the outcome analysis with words. It means that the results can be represented using words or phrases. The result was presented by using words and sentences and to make the readers easily understand.

\section{Results and Discussion}

From the analysis of "Anger Management movie"Dorfman (2013). The researcher found 20 data were found which including to illocutionary act. The data included to directive, representive, commisive, expressive, and declarative. from the data, there are 20 data included to illocutionary act like:

Table 1. The types of Illocutionary Acts in Anger Management movie No Types of Illocutionary total Amount

1. Directive 8

2. Declarative 5 
3. Commisive 2

4. Expressive 4

5. Assertive 1

total number of data 20 data

\section{Assertive}

\section{Data 1:}

Dr. Buddy: ...and tell them 1 don't have an anger problem if you want. I can't just sign your papers.

Dave: I didn't do anything wrong.

This sentence happened when Dr. Buddy knew that Dave's case in the airplane while during his flight for working. Dave was accused by violence in the airplane. This is the data of representative type, because he conveyed his belief that some proposition is true and he claimed his belief that he did nothing wrong.

\section{Expressive}

\section{Data 1:}

Dave: I'll see you soon. The Yanks are great this season.

In this data, Dave watched football game in the bar. And he loved to watch The Yanks his favorite one. So he was happy when he knew Yank was the great this season. He expressed happy and praises because he believed that he would be satisfied got this great news. Illocutionary happened when someone is clear that the utterance.

\section{Data 2:}

Dave: Buddy Rydell, you're a great man.

Dr. B: I was just doing my job.

In this data, Dave finished his anger management class. He thanked to Dr. Buddy for giving him a great class and care. This is one of expressive type because of when seeing the word "great." It meant that he satisfied got the care from Dr. Buddy. Illocutionary could be happen when someone had a clear utterance.

\section{Data 3:}

Dr. Buddy: Dave, cooking is very relaxing and therapeutic.

In this data, Dr. Buddy slept in Dave's house for a night during the anger management. Dr. Buddy said that "cooking is very relaxing and therapeutic". Based on the utterance, it can be seen that relaxing is one of the expressive type. He expressed happy and praises because he believed that he would be satisfied got this great news.

\section{Data 4:}

Galaxia: you don't let me out there you grew melons in love very much. I can't stop love

Dave: thank you.

In this data, Galaxia give some advice that if he love someone you can tell to her. In the conversation, Dave said thank you to express that he said thank to Galaxia. 


\section{Commisives}

\section{Data 1:}

Dave: I can't believe you actually started to fall for that crazy man.

This sentence is the illocutionary act. The type is commisive. This data happened when Dave said that "he can't believe that his girlfriend loved his doctor. Based on that commisive express what the speakers intend. Dave expressed his intention about Dr. Buudy and his girlfriend by refuse it that they had a relationship.

\section{Data 2:}

Dave : uh miss..

Fight attendent: I'll be right there sir

This sentence is the illocutionary act. In the airplane when Dave said "uh miss" the flight attendent looke for him and said I'll be right there sir. The data was express commisive because the flight attendenr promise to meet him in the future after she finished her job.

\section{Directive}

\section{Data 1:}

Linda: When you hear what happened, you'll bow down and worship me like a god. Dr. B: Better be good. Give it to me.

This sentence is the act of directive illocutionary act. The situation happened when Dr. B said "Give it to me," he requested Linda just to be relax and let him handled it. Directive is speaker used to get someone else to do something or speaker's intention. Also this illocutionary act is the kinds of directives that has a force for commanding. It was clear that the utterance was requesting.

\section{Data 2:}

Dr. Buddy: Confidence is the key to winning a young lady's attention. Now, listen to me very carefully.

From the utterance, Dr. Buddy said to Dave to listen him carefully how to get the lady's intention. This is the data with the directive illocutionary act type. Dr. B represented it to get Dave as addressee to listen to him. Dr. B wanted to explain something and more about how to get the lady. It was clear that the utterance is requesting.

\section{Data 3:}

Dr. Budyy: Do you know "I Feel Pretty"?

Dave: I want you to get out.

This sentence is the act of directive illucotionary act. The situation happened when Dr. B said "do you know I feel pretty?," he requested Dave to sing that song. But because Dave was angry so he did not want to sing that and asked Dr. B to stop and get out from his house. This is one of the directive is because the speaker used to get someone else to do something or speaker's intention. Also this illocutionary act is the kinds of directives that had a force for commanding. It was clear that the utterance was requesting. 


\section{Data 4:}

Dave : man...

Flight attendent: could you give me a second sir?

This sentence is the act of directive act. the situation happened when Dave called the flight attendent and the flight attendent said "could you give me a second sir?". The utterance of the speaker had intended meaning for requesting.

\section{Data 5:}

Dave: please marry me..

This sentence is the act of directive act. the situation happened when Dave said "please marry me" he requested Linda to marry him and became Dave as husband. Also this illocutionary act is the kinds of directive that has requesting.

\section{Data 6:}

Dave : I am like playing tennis on occasion

Dr. Buddy: ...also not your hobby just simple tell us who you are?

This sentence is the actof directive act. in this data told about request Dave told about the identity personal not the hobby or etc. In this data clear that the utterance was requesting.

\section{Data 7:}

Dave: excuse me..could you a drink I mean I see that you have a drink... Michelle: bite me..

Dave: nice living you ok..

Based on the conversation above Dave wanted to buy some drinks to the woman. Here Dave acted to request to buy some drinks to Michelle. It was clear that the utterance is requesting. The second Michelle said "bite me", the utterance made command in a way refused. So that Dave said "nice living you" he made action that he accepted her refused.

\section{Declarative}

\section{Data 1:}

Dave: Well, the hell with this! I'm going home!

This sentence is the act of declarative illocutionary act, because he was tired to see and join the class anger management. This utterance was clearly declared that he did not want to have the class. It was clear that the utterance was declaring.

\section{Data 2:}

Air Marshall: I'm only gonna say this one more time sir calm down okay!!!

This sentence is the act of declarative act, because Air Marshall said to Dave to calm down, but dave did not hear him. This utterance was declared that he shouted "calm down" to calm him.

\section{Data 3:}

Dave: I won't let you do this to us! Don't marry him!

This utterance happened when Dave did not feel good because of his girlfriend wanted to marry another man. Because of that, it was called as the act of declarative illocutionary act, because he was trying to inform his girlfriend not to 
marry Dr. B without he knew that it was mistaken. This utterance was clearly declared that she did not want her to marry anyone else. It was clear that the utterance was declaring.

\section{Data 4:}

Dave:....... I believe in us Linda I love you with all my heart and you love me back..

Based on the example of the data. Dave declarat in the stadion. He shouted tthat he loved Linda very much and to get her husband. This statement declarate about love.

After analyzing the data, the research found some findings. There are three types of speech act. From the 20 data that researcher collected there are 1 assertive data, 4 expressive illocutionary acts, and 2 commissive illocutionary, 8 data for directive illocutionary act, and 5 data for declarative data. From all the data, the most used type of illocutionary is 4 data for expressivee, 5 data for declarative and also 8 data for directive. It happened because some people wanted to describe their feeling through their expression and people also liked to asked people not to do or do something by using directive illocutionary act.

\section{Conclusion}

The conclusion that can be taken is this paper explained about the type of illocutionary act. Illocutionary is what is achieved by communicating the intention to achieve something. Speech can contain certain 'power'. In this case, the researcher used the movie to take this data from the utterance during the Anger management movie. There is still a lack of references regarding the analysis of illocutionary speech acts on Anger management movie, making researchers interested and hoping this research will be continued and became more variatiation. There are three types of speech act. From the 20 data that researcher collected there are 1 assertive data, 4 expressive illocutionary acts, and 2 commissive illocutionary, 8 data for directive illocutionary act, and 5 data for declarative data. From all the data, the most used type of illocutionary is 4 data for expressive, 5 data for declarative and also 8 data for directive. It happened because some people wanted to describe their feeling through their expression and people also liked to asked people not to do or do something by using directive illocutionary act.

\section{References}

Austin, J. L. (1962). How do to Things with Words (p. 167). p. 167. https://doi.org/10.1093/acprof:oso/9780198245537.001.0001

Aziz, J. A., Mahdi, S., \& Amalia, R. M. (2017). Directive Illocutionary Acts by Mario Teguh in "Super Show" Talk Show : A Pragmatics Study. Journal of Pragmatics, 16-17.

Dorfman, B. D. (2013). Anger Management. 
Hughes, J. (1984). Justin hughes. Linguistics and Philosophy, 7, 379-395.

Jacobs, S. (1989). Speech Acts and Arguments. Argumentation, 3, 345-365.

Leech, G. (1989). Principles of Pragmatics Longman Linguistics Library.pdf.

Masruddin, M. (2018). Lessons in Old Man and The Sea. IDEAS: Journal on English Language Teaching and Learning, Linguistics and Literature, 1(1). doi:https://doi.org/10.24256/ideas.v1i1.126

Munawir, A. (2019). Online Game and Children's Language Behavior. IDEAS: Journal on English Language Teaching and Learning, Linguistics and Literature, 7(2). doi:https://doi.org/10.24256/ideas.v7i2.1050

Nurul, A. (2019). Anderson Taxonomy-Based Intensive Test Evaluation Tool for Senior High School. IDEAS: Journal on English Language Teaching and Learning, Linguistics and Literature, 7(1). doi:https://doi.org/10.24256/ideas.v7i1.725

Rusdiansyah, R. (2019). Note-Taking as a Technique in Teaching Reading Comprehension. IDEAS: Journal on English Language Teaching and Learning, Linguistics and Literature, 7(2). doi:https://doi.org/10.24256/ideas.v7i2.1033

R, S. J. (1968). bookj 3.pdf.

Searle, J. R. (1969). Speech Acts: An Essay in the Philosophy of Language [Taschenbuch].

Sembiring, W. A. (2019). Illocutionary Acts on Aladdin Movie 2019. Journal Basis, 2(October), 277-284.

Sudaryanto. (1993). Method dan teknik analysis bahasa. Yogyakarta: Duta Wacana University Press.

Yule, G. (2010). The study of language (4th ed.). New York: Cambridge University Press. 